\title{
PROFESSIONAL-SYNERGETIC SCIENTIFIC-METHODIC COMPETENCY OF TEACHERS IN THE POSTGRADUATE PEDAGOGICAL EDUCATION SYSTEM
}

\author{
S. Tolochko
}

У даній статті проаналізовано синергетичні параметри педагогіки як детермінанти креативного навчання, виявлено концептуальні, теоретико-методологічні, функиіональні та компетентнісні засади становлення синергетичної педагогіки як нової міждисииплінарної галузі професійно-педагогічної діяльності. Визначено в авторській дефініиї трактування поняття «синергетично-інтегрована науковометодична компетентність викладачів» як багатокомпонентна інтегральна система рівнозначних загальних (універсальних, ключових) та професійних компетентностей, реалізована наскрізно на всіх етапах навчання впродовж життя через об'єднання, взаємне використання та доповнення форм, методів, засобів і технологій, створення наукоємкого методичного супроводу освітнього процесу та на основі цьього продукування наукових положень і аргументованих результатів унаслідок здійснення досліджень у певній галузі науки, які вирішують складні науково-теоретичні чи практичні проблеми. Означено й конкретизовано системні якості, здатності, здібності, готовності, сформованості формування професійно-синергетичної науково-методичної компетентності викладачів.

Деталізовано иінність професійно-синергетичної науково-методичної компетентності викладачів, щзо зумовлюється ї̈ функиіями: для викладачів: самовизначення, самомотивування; саморефлексії та творчості; самонавчання, самовдосконалення та саморозвитку; самореалізації та саморегулячії; адаптивно-сочіалізуюча; егозахисна, самопрофілактики та самореабілітації; для персоналу закладів післядипломної педагогічної освіти: діагностично-моніторингова; організаційно-проектна; методичнометодологічна; партнерсько-сочіалізуюча; психологічно-емоційна; підтримуючо-реалізаційна; аналітико-регуляційна.

Конкретизовано, що залежно від змісту професійно-синергетичної науково-методичної компетентності педагогів, викладачів та рівнів ї̈ когнітивної й технологічно-операційної складових визначено основні функиіональні групи часткових компетентностей: функціонально-філософська, загальнонаукова, конкретно-наукова науково-методична компетентність та визначено їх структуру з метою визначення категоріального апарату та термінологічної бази даного дослідження.

Підсумовано, щчо ефективність формування професійно-синергетичної науково-методичної компетентності викладачів у системі післядипломної педагогічної освіти, на нашу думку, залежатиме від інтеграції можливостей ї̈ реалізацї у формальній, неформальній та інформальній освіті. Педагогу, викладачеві життєво важливо здійснювати неперервну професійну освіту, застосовуючи інновачійні форми й методи, формуючи особистість здобувачів освіти, а також демонструючи таке ставлення до навчання на своєму прикладі, реалізуючи власну індивідуальну освітню траєкторію

Ключові слова: професійно-синергетична науково-методична компетентність викладачів, функціонально-філософська, загальнонаукова, конкретно-наукова, післядипломна педагогічна освіта

Copyright (C) 2019, S. Tolochko.

This is an open access article under the CC BY license (http://creativecommons.org/licenses/by/4.0).

\section{Introduction}

Our society determines learning during life as a leading idea of education renovation. Accordingly, the role of pedagogical workers (PW) and scientificpedagogical ones that teach and train applicants of education (students, pupils, listeners of courses) for satisfying needs of the present labor market and realization of the necessity of postgraduate education grows. Today needs from specialists not separate knowledge in a certain branch of science, but the integrity of functioning and development of the educational sphere as a whole, interdisciplinary, transdisciplinary, integrative, system character, orientation on the formation of the society for an educated personali- ty, rational society and development of the civilization of global education and science. But today it is not expedient to teach youth by the principle of a single correct answer. In the information society the necessity of system mastering of professional-synergetic scientific methodical competences by teachers of postgraduate pedagogical education (PPE) grows.

\section{Literary review}

The analysis of pedagogical-psychological literature testifies to the considerable interest to the problem of determination, formation and development of competences of PW and SPW in the system of postgraduate pedagogical education (PPE). 
Thus, synergetic parameters of pedagogy as a determinant of creative learning are discovered in [1], conceptual, theoretical-methodological, functional and competence formation principles of synergetic pedagogy as a new interdisciplinary branch of the professionalpedagogical activity are revealed in [2]. The modern condition of the sphere of education management: analysis of a managerial staff is studied in [3], theoretical substantiation of the necessity of forming the professionalsynergetic scientific methodical competence of teachers in the system of postgraduate pedagogical education in [4]. The scientific-research component of the professional-synergetic scientific methodical competence of teachers in the system of postgraduate pedagogical education is studied in detail in [5], requirements as to the integral competence of a pedagogical and scientific-pedagogical staff for the system of postgraduate pedagogical education are concretized in [6]. The increase of interdisciplinary integration in the educational process and through web-video-series is presented in [7]. The methods of teaching students on the cross of disciplines and cultures and also theory and practice are presented in [8]. The professional competence of teachers in the century of globalization in the world is presented in [9]. The methodology of expert estimation of cognition results, development programs and plans is discovered in [10].

But despite such detail analysis of requirements to the competence of PW and PSW, the question of forming the professional-synergetic scientific methodical competence of teachers in the system of postgraduate pedagogical education remains little studied.

\section{Aim and tasks of the research}

The aim of the research is to determine the essence and structure of the professional-synergetic scientific methodical competence of teachers in the system of postgraduate pedagogical education.

The following tasks were set for attaining this aim:

- to analyze the topicality of synergetic pedagogy for the system of postgraduate pedagogical education;

- to concretize functions and levels of the scientific methodical competence of teachers;

- to specify the content of the terms "professional-synergetic scientific methodical competence of teachers", "functional-philosophical, general scientific, concrete-scientific scientific methodical competence" and to determine their structure for defining the categorical apparatus and terminological base of this study.

4. Theoretical-methodological aspects of substantiating the determination of the essence and structure of the professional-synergetic scientific methodical competence of teachers in the system of postgraduate pedagogical education

Synergetic pedagogy is an advanced interdisciplinary branch of pedagogical and synergetic science that studies formation and development properties of a human of the modern socio-natural generation at its upbringing, formation as a convinced subject, responsible for preservation of the life activity environment and professional development during the whole life. It is grounded on correspondent worldview ideas, namely:
- favoring of the development of a person for his/her self-discovery and self-improvement, selfactualization in the process of cooperation with other people and with him/herself;

- development of integration of different ways of world mastering by a human (art, philosophy, mythology, science and so on), at that the development of integration must be based on holistic tendencies of ideas about the objective reality;

- change of the role of a teacher, educator, professor that provides the transfer to common actions of all participants of the learning-upbringing process in new situations in the open, flowing, irreversible world;

- elaboration of a modern model of the pedagogical profession in the context of social needs, development prospects of the national economy and global technological changes and so on.

\section{Results of the research}

The studies, conducted by us, make possible the following interpretation of the notion "synergetic integrated scientific methodical competence of teachers" (SiSMC) - a multi-component integral system of equivalent general (universal, key) and professional competences, realized through all learning stages during life by combining, mutual using and adding forms, methods, means and technologies, creating the science-consuming methodical support of the educational process and based on it, scientific statements and argued results as a consequence of making studies in a certain field of science, solving complicated scientific-theoretical or practical problems. sented in:

This competence of a teacher, educator is repre-

- system qualities: purview, erudition, scientific intellect, humanism, humanitarian thinking; social justice, intellectual character, purposefulness, mobility, dynamism of a personality, adaptability, multiculturalism, tolerance, empathy, emotional intellect, expressiveness, developed speech, artistry, optimism and so on;

- talents: to scientific cognition, analytic-thinking activity, system analysis, quality of components of the social and educational environment, sciencemetry, system-pedagogical management, prognostication, modeling and planning and so on;

-abilities: to perceive, to systematize and to translate scientifically grounded information, to study the environment (social, educational), age transformation of a target material for different training categories, ability to methodical, social work, artistic and aesthetic comprehension of reality, moral-ethic attitude to a person, ability to bioethics, ecological ethics and so on;

- readiness: professional self-consciousness and realization of the pedagogical activity, according to standards, concentration of the professional (spiritual, personal and physical) potential, psychological readiness (psychological self-regulation, activity in non-standard conditions, ability to foresee, anticipate future, to produce a certain reaction to them), ability to self-regulation, wide use of information-TV-communication-multimedia means in the educational process, social responsibility and so on; 
-formation of complex-creating and integrated imperative, totalization of partial competences (functional-philosophical: philosophical, religion studying, worldview, civilization, moral-ethical, artisticaesthetical, self-educative, critical thinking; general scientific: research-experimental, creative, informationdigital, innovative, reflexive, andragogical, managerial, monitoring-expert, prognostic-modeling; concretescientific (professional): pedagogical, psychological, mathematical, naturalistic, ecological, technical, technological, historical, logical, legal, political, social, sociological, language-communicative, instrumental-analytic and so on).

The importance of the professional-synergetic SMC of teachers for the professional activity under conditions of adult education is conditioned by its functions.

Depending on conception tasks, teachers' functions include: self-determination, self-motivation; selfreflection and creativity; self-education, selfimprovement and self-development self-realization and self-regulation; adaptive socialization; ego-protection; self-prophylaxis and self-rehabilitation; ones of a staff of postgraduate pedagogical educational institution as pedagogues-andragogues (continuous and successive influence on teachers of academic subjects) are: diagnosticmonitoring functions; organizational-projecting; methodical, methodological; partner-socializing; psychologicalemotional; supporting-realizing; analytic-regulating.

The formation of the professional-synergetic scientific methodical competence of teachers in the system of postgraduate pedagogical education is, first of all, the process of creative self-discovery of a personality of PW and SPW, renovation of their activity, manifested through the innovative combination, modernization and re-discovery of contents, methods and forms of learning, actualizing such factors as openness, self-organization, ability to communication, creativity and non-linearity, critical thinking, control, self-control, self-management, work in team and so on.

The content of the professional-synergetic SMC of teachers, educators is a totality of components: cognitive (provides mastering of knowledge, according to the determined methodological levels: fundamentalphilosophical, general scientific, concrete scientific (professional) and technological-operative (provides mastering of skills and competences of the didactic, methodical and technological character).

Let's consider the cognitive component through the analysis of definitions of its levels.

Fundamental-philosophical level of the cognitive component of the synergetic SMC is key principles of cognition and notional-categorical apparatus of science as a whole that is the significative base of knowledge, presenting different approaches to the process of comprehension and transformation of reality.
The general scientific level includes conceptions, paradigms, approaches, principles, regularities, used in sciences branches by generalization, systematization of scientific researches. It is characterized by perceiving real phenomena as systems by their construction and activity laws. In the context of our research this level is grounded on the idea of the necessity of education continuousness, correspondence between old and new laws, conceptions, models of teacher's competences in the system of postgraduate education for the sustainable development.

The concrete-scientific one is a totality of notions, techniques, methods, research principles and procedures, used in one or another special scientific discipline. Modern science has numerous researches, devoted to the ratio of the methodology of pedagogy and its branches in the development and mutual connection that appear at the boundary between sciences, so-called interdisciplinarity.

The technological-operative component of the scientific-methodological competence consists of the method and technology of the study (determination of the role and place of methodological knowledge in the system of learning, ability to use scientific methods on a concrete material, to use techniques of systematization, generalization, classification, integration of interdisciplinary knowledge and also the ability of a teacher, educator to orient in the informational space, to use technical and multimedia means, to possess and to operate information, according to professional needs, to estimate an achieved result). At this level methodological knowledge has a distinctly expressed normative character.

SiSMC of teachers in the system of PPE is a totality of complex-creating and integrated imperative of partial competences, formation of each of them is one of parameters of the general degree of the scientificmethodological competence.

Depending on content of the synergetic SMC of teachers, educators and levels of cognitive and technological operational components, main functional groups of partial competences are determined (Table 1 "functional groups of the professional-synergetic scientific methodical competence of teachers"

Competences of each functional group have a certain educational potential, necessary for forming parallel integral competences, and are included to SiSMC of teachers. The creatively formed SiSMC testifies to the highest realization level of this potential, embodied through the process of learning each discipline or course at qualification improvement, re-training, probation.

The effectiveness of forming the professionalsynergetic scientific methodical competence of teachers in the system of postgraduate pedagogical education, from our point of view, depends on integration of possibilities of its realization in formal, non-formal and informal education. 
Functional groups of the professional-synergetic scientific methodical competence of teachers

\begin{tabular}{|c|c|c|}
\hline $\begin{array}{c}\text { Functional-philosophical scientific- } \\
\text { methodological competence }\end{array}$ & $\begin{array}{c}\text { General scientific- } \\
\text { methodological competence }\end{array}$ & $\begin{array}{c}\text { Concrete scientific- } \\
\text { methodological competence }\end{array}$ \\
\hline $\begin{array}{c}\text { Philosophical } \\
\text { Religion studying } \\
\text { Worldview } \\
\text { Civilization } \\
\text { Moral-ethical } \\
\text { Artistic-aesthetical } \\
\text { Logic } \\
\text { Culturological Multicultural } \\
\text { Rhetorical } \\
\text { Heuristic } \\
\text { Cosmopolitan } \\
\text { Humanitarian } \\
\text { Self-educative } \\
\text { Critical thinking } \\
\text { Civic }\end{array}$ & $\begin{array}{c}\text { Scientific-research-experimental } \\
\text { Experimental } \\
\text { Methodological } \\
\text { Creative } \\
\text { Informational-digital } \\
\text { Media-competence } \\
\text { Innovative } \\
\text { Interpreting } \\
\text { Inclusive } \\
\text { Reflexive } \\
\text { Androgogical } \\
\text { Socio-economic } \\
\text { Scientific-methodical } \\
\text { Emotional-intellectual } \\
\text { Managerial } \\
\text { Monitoring-diagnostic } \\
\text { Expert } \\
\text { Prognostic-modeling } \\
\text { Qualitologic } \\
\text { Sciencemetric } \\
\text { Futuristic } \\
\text { Health-protective } \\
\text { Stable }\end{array}$ & $\begin{array}{c}\text { Pedagogical Psychological, Mathe- } \\
\text { matical Naturalistic } \\
\text { Ecological } \\
\text { Historical } \\
\text { Political } \\
\text { Social } \\
\text { Legal } \\
\text { Language-communicative Instru- } \\
\text { mental-analytic } \\
\text { Technical } \\
\text { Technological }\end{array}$ \\
\hline
\end{tabular}

So, the Ukrainian society needs a modern pedagogue, teacher - an integral personal, able to selfcognition and self-development that combines in him/herself the new qualities and pedagogical reputation and is ready to teach to use knowledge, abilities and skills, competences, is striving to get and to acquire new ones, improving methods of their use. It is vitally important for a pedagogue, a teacher to realize continuous professional education, using innovative forms and methods, forming a personality of students and also demonstrating such attitude to learning on own example, realizing own individual educational trajectory.

\section{Conclusions}

1. The topicality of synergetic pedagogy for the system of postgraduate pedagogical education is analyzed.

2. functions and levels of the scientific methodical competence of teachers are concretized.

3. The content of the terms "professionalsynergetic scientific methodical competence of teachers", "functional-philosophical, general scientific, concretescientific scientific methodical competence" are specified and their structure for defining the categorical apparatus and terminological base of this study is determined.

\section{References}

1. Ziaziun I. A. Synerhetychni parametry pedahohiky yak determinanty kreatyvnoho navchannia // Kreatyvna pedahohika. 2012. Issue 5. P. 7-13.

2. Synerhetychna pedahohika: handbook / Isaienko V. M., Ridei N. M., Navrotska D. V., Bohutskyi Yu. P., Ulishchenko A. B. Kyiv, 2019. $416 \mathrm{p}$.

3. Ridei N. M., Bohutskyi Yu. P., Sholudiak A. A. Suchasnyi stan doslidzhennia u sferi upravlinnia osvitoiu: analiz kerivnytstva VNZ // Nova pedahohichna dumka. 2015. Issue 3. P. 2-30.

4. Tolochko S., Ridey N. Theoretical substantiation of the necessity of formation of scientific-methodological competence of teachers in the system of postgraduate pedagogical education // ScienceRise: Pedagogical Education. 2017. Issue 8 (16). P. 14-19. doi: http://doi.org/10.15587/2519-4984.2017.108974

5. Tolochko S. V. Naukovo-doslidnyi komponent naukovo-metodychnoi kompetentnosti vykladachiv u systemi pisliadyplomnoi pedahohichnoi osvity // Nova pedahohichna dumka. 2017. Issue 3 (91). P. 14-18.

6. Tolochko S. Integrated competence of teaching and academic staff for the system of postgraduate pedagogical education // ScienceRise: Pedagogical Education. 2019. Issue 1 (28). P. 22-29. doi: http://doi.org/10.15587/2519-4984.2019.155145

7. Increasing undergraduate interdisciplinary exposure through an interdisciplinary web-based video series / Hammons A. J., Fiese B., Koester B., Garcia G. L., Parker L., Teegarden D. // Innovations in Education and Teaching International. 2019. P. 1-11. doi: http://doi.org/10.1080/14703297.2019.1635902

8. Karen P. I., Bush S. R. Educating students to cross boundaries between disciplines and cultures and between theory and practice // International Journal of Sustainability in Higher Education. 2010. Vol. 11, Issue 1. P. 19-35. doi: http://doi.org/10.1108/14676371011010020

9. Orazbayevaa K. Professional Competence of Teachers in the Age of Globalization // International Journal of Environmental \& Science Education. 2016. Vol. 11, Issue 9. P. 2659-2672. 
10. Ridey N. M., Tolochko S. V. Methodology of expert assessment of the results of cognition, programs and development plans // Development and modernization of pedagogical and psychological sciences: experience of Poland and prospects of Ukraine. Vol. 3. 2017. P. 170-189.

Рекомендовано до публікачії д-р пед. наук, професор Боголюбов В. М.

Received date 21.05.2019

Accepted date 06.06.2019

Published date 31.07.2019

Svitlana Tolochko, PhD, Department of Management of Vocational Education, National Aviation University Kosmonavta Komarova ave., 1, Kyiv, Ukraine, 03058

E-mail: svitlana-tsv@ukr.net; tolochkosvitlana331@gmail.com

УДК 374.32: 396.4

DOI: $10.15587 / 2519-4984.2019 .174586$

\title{
ІМПЛЕМЕНТАЦІЯ ДОСВІДУ ПРОФЕСІЙНОЇ ПІДГОТОВКИ І ВИХОВАННЯ ДІВЧАТ УКРАЇНСЬКОЇ ДІАСПОРИ У ЗМІСТ РОБОТИ «ШКОЛИ ШЛЯХЕТНИХ УКРАЇНОК»
}

\author{
О. В. Джус
}

У статті розкрито сутність імплементації досвіду професійної підготовки і виховання дівчат української діаспори у зміст діяльності «Школи шляхетних українок» м. Болехова (Долинський р-н ІваноФранківської обл. (1996-2001) та Львова (з 2009), простежено їх роль у національно-громадянському становленні украӥнської молоді, з'ясовано вплив роботи иьього позашкільного навчально-виховного закладу на розгортання діяльності аналогічних інституцій у сучасній Україні.

Досліджено, щз прототипом створення мережі шкіл для дівчаток можна вважати «Школу шляхетних украӥнок» у м. Болехові Долинського району Івано-Франківської області під керівництвом Лариси Дармохвал (голови Союзу українок Болехова). Вона продовжила кращі традиції жіночих шкіл Галичини кінця $X I X-$ початку XX ст., які, своєю чергою, повною мірою зреалізували своє завдання в еміграції, стали потужною опорою для формування освіти для жінок в украӥнській діаспорі, відкрила нову сторінку в історї освіти дівчат західного регіону Украӥни і надихнула на творення мережі подібних навчально-виховних закладів у інших населених пунктах нашої держави.

Акцентовано на діяльності болехівських членкинь Союзу украӥнок у сфері виховання украӥнських дівчат та піднесенні духовності жінок краю, яку продовжили з 2009 р. жінки Львівщини на чолі з Ростиславою Федак (заступник голови Союзу українок України й ініціатор створення Школи у Львові). Аналіз регіональної Програми «Школи шляхетних українок» 2009/2010 н. р. засвідчив, щзо метою школи стало виховання нової генерачії громадських діячок, освічених громадянок, які зуміли б не тільки будувати свою родину і захищати ї̈, але й були основою розбудови громадянського суспільства, правової незалежної держави, зразком духовності, культури.

Акцентовано на ролі у професійному становленні дівчаток-учениць школи визначних культурно-освітніх діячів української еміграції, імплементації європейського досвіду у їх фахову орієнтачію. Продовжуючи кращі традищї жіночих освітніх інститущій украӥнської діаспори «Школа иляхетних украӥнок» $і$ сьогодні відкриває нові сторінки в історії освіти дівчат регіону, надихає до прачі $і$ служіння на користь Украӥнської держави

Ключові слова: імплементація, діаспора, освіта дівчат, «Школа иляхетних украӥнок», національногромадянське виховання

Copyright (C) 2019, О. В. Джус. This is an open access article under the CC BY license (http://creativecommons.org/licenses/by/4.0).

\section{1. Вступ}

Якісно нові зміни в українському суспільстві актуалізують проблеми пов'язані із забезпеченням паритетного становища представників обох статей у громадсько-політичній, соціально-економічній і культурно-освітній сферах та поглиблення і розширення відомостей про місце і роль жінки у загальнонаціональному та духовно-інтелектуальному поступі. 